\author{
Jiaohua ZHANG, \\ orcid.org/0000-0002-3585-516X \\ Graduate Student at the Department of Fine Arts, \\ Musicology and Cultural Studies \\ Sumy State Pedagogical University named after A. S. Makarenko \\ (Sumy, Ukraine) czaohuaczan@gmail.com
}

\title{
TECHNOLOGICAL ASPECTS OF PIANO SOUND FORMATION
}

Outlining the specifics of sound formation on the piano makes it possible to deepen the idea of piano intonation, which is inseparable from the artistic idea, the leading source of choice of means of musical expression, methods of formation and reproduction of sounds; outline new approaches to the tasks that arise in the practical activities of the pianist-performer. The purpose of the article is to study the mechanical and acoustic features and properties of the piano in an integral relationship with the organization of the musical form and artistic means of performance, formed in the process of musical practice. The methodological basis of the study are dialectical and systemic methodologies used in the field of cultural studies. General scientific and logical methods of analysis, synthesis, induction and deduction, historical and comparative research of the problem are used. The article is an attempt to explore the specifics of piano intonation in the performing arts, to reveal the intonation specifics of the piano. The author describes three stages of piano sound production, as well as issues directly related to piano sound production: the techniques of sound production on the piano and the impact of dynamics and pedaling on it. The practical significance lies in the possibility of using the main provisions of the article when writing scientific papers on relevant topics, in the process of teaching professional disciplines. The results of the study can be implemented in concert-performing and pedagogical activities, be used in the organization of musical and cultural life. Conclusions. Conscious piano intonation, being the sound embodiment of musical thought, finds its direct expression through the specifics of sound production on the mentioned instrument, which is inextricably linked with the techniques of sound production, dynamics, pedaling.with sound production techniques, dynamics, and pedalization.

Key words: piano, piano sound generation, piano sound extraction, dynamics, pedalization.

Цзяохуа ЧЖАН,
огсіd.оrg/0000-0002-3585-516Х
аспірант кафедри образотворчого мистецтва, музикознавства та культурології
Сумського державного педагогічного університету імені А. С. Макаренка
(Суми, Украӥна) сzаоһиасzап@gmail.com

\section{ТЕХНОЛОГІЧНІ АСПЕКТИ ФОРТЕПІАННОГО ЗВУКОУТВОРЕННЯ}

\begin{abstract}
Окреслення специффіки звукоутворення на фортепіано дає можливість поглибити уявлення про фортепіанне інтонування, яке є невіддільним від художнього задуму, провідним джерелом обрання засобів музичної виразності, способів формування та відтворення звуків; окреслити нові підходи до завдань, які виникають у практичній діяльності піаніста-виконавия. Мета статті полягає в дослідженні механіко-акустичних особливостей та властивостей фортепіано у иңілісному співвідноменні з організацією музичної форми та художніми засобами виконання, щзо сформувались у проиесі музичної практики. Методологічну основу дослідження становлять діалектична та системна методології, що застосовуються в області культурологічних досліджень. Використано загальнонаукові та логічні методи аналізу, синтезу, індукиії $i$ дедукиії, історичного $і$ компаративістського дослідження проблеми. Стаття є спробою дослідити специфіку фортепіанного інтонування у виконавському мистеитві, розкрити інтонаиійну специфіку фортепіано. Автором охарактеризовано три етапи фортепіанного звукоутворення, а також розглянуто питання, безпосередньо пов'язані з фортепіанним звукоутворенням: прийоми звуковидобування на фортепіано та вплив на нього динаміки і педалізачії. Практичне значення полягає в можливості використання основних положень статті під час написання наукових праць на відповідну тематику, в процесі викладання фахових навчальних навчальних дисииплін. Результати дослідження можуть бути впроваджені в концертно-виконавську та педагогічну діяльність, бути використані у сфері організації музичнокультурного життя. Висновки. Усвідомлене фортепіанне інтонування, будучи звуковим втіленням музичної думки, знаходить своє безпосереднє вираження через специфіку звукоутворення на згадуваному інструменті, яке нерозривно пов'язане із прийомами звуковидобування, динамікою, педалізацією.
\end{abstract}

Ключові слова: фортепіано, фортепіанне звукоутворення, фортепіанне звуковидобування, динаміка, педалізація. 
Introduction. In a music piece, intonement is inseparable from the artistic concept, it is a leading source of choice of musical expression means, ways of forming and reproducing sounds. Therefore, the study of the problem of piano intonement is inextricably linked with the awareness of the specifics of sound formation on the studied instrument. From D. Kirnarska's point of view, the sound provides rather accurate information about the surrounding world with its timbre, articulation, pitch and volume. These sound properties "determine the character of the music and its actual sound as well as the reaction to it" (Кирнарская, 2004: 63).

As H. Neuhaus noted: “...Mastering the sound is the most important task that arises among other piano technical problems a pianist must solve. After all, sound is actually musical matter; by perfecting and enriching it, we lift music to a higher level» (Нейгауз,1988: 143). Reflecting on the peculiarities of piano sound, Neuhaus wrote that among other instruments, the piano is the best actor, as it can perform a variety of roles. The piano is «an intellectual instrument and does not have sensual flesh of other instruments" (Нейгауз, 1988: 143).

Consideration of playing techniques used by the pianists-performers in their practice, as well as answers to the questions what factors influence the piano sound formation, why the same techniques form a sound with different characteristics, will allow to deepen the idea of piano intonement, which is inseparable from the artistic concept and to define new approaches to the problems that arise in the practice of a pianist-performer.

Analysis of recent research and publications. The methodological basis for the study of piano intonement is the theory of intonation of B. Asafiev (Асафьев, 1971), whose provisions are used in modern linguistics, semiotics, acoustics, psychology, physiology, aesthetics etc. At the same time, the views on piano intonement in the performing arts are described only in separate works by V. Colonei, who considers piano performing intoning as an organic unity of a sound purpose (sound intoning) and a way of achieving this purpose in somatic intoning (Колоней, 2004), A. Malynkovska, whose monograph is devoted to the problems of artistic intoning on piano and analysis of their development in the methodological and theoretical literature of XVI-XX centuries (Малинковская, 2019). In $\mathrm{T}$. Vierkina's dissertation "Actual intoning as a performing problem" (Вєркіна, 2008) displays musical and performing art as a creative practice, a way of fixation, reproduction and development of musical experience of a person; works of Ye. Bon- dar reveal the problem of super-expressive intonation in the context of contemporary choral art (Бондар, 2005).

The objectives and tasks of the article are to study the mechanical and acoustic features and properties of piano in the integral relationship with the organization of the musical form and artistic means of performance, formed in the process of musical practice. Revealing of the objectives of the article is realized through the study of playing techniques used in their practice by pianists, factors that influence the formation of piano sound; finding out why essentially the same techniques produce sound with different characteristics.

The methodological basis of the study is the dialectical and systemic methodologies used in the field of cultural studies. General scientific and logical methods of analysis, synthesis, induction and deduction, historical and comparative research of the problem are used.

Statement of basic materials. Taking a separate tone as a basis and "micro unit of the intonation process" (Малинковская, 2019: 70), we trace the following stages of sound formation on the piano:

1) a hammer blow on the string, which leads to its oscillation;

2) sound (length) of tone with its gradual subsidence (the main part of the sound);

3 ) raising the finger from the key and lowering the damper, which causes the damping of this oscillation.

Thus, at stage I - the attack of the sound - the percussive principle of sound production finds its manifestation: dismemberment of the sound flow by internal impulses, as well as its energetic-tonic, motor start. Its dialectical opposite is stage III, which manifests itself by raising the finger from the key and lowering the damper, leading to the damping of this oscillation. It should be noted that usually this stage is paid less attention, despite its obvious importance.

Stage II - the sound of the tone is caused by several factors:

- the power of influence on the string;

- the mass of the vibrator (the lower the tone, the greater the mass of the string, and the longer the string sounds towards its natural end) as a resonator.

Thus, the process of controlling a single tone reproduced on the piano is almost impossible, and in dynamic terms, the sound of the tone tends to subside. At the same time, in order to continue the sound, the pianist can imitate the effect of bebung (vibrato effect) by creating a vibration with soft pedal pulses (the so-called damping vibrato) or by double rehearsal with his fingers (L. Beethoven sonata op. 106 (Adagiosostenuto, vol. 156; sonata op. 110 (Adagionontroppo, vol. 5)). 
Hereunder we consider the issues directly related to piano sound production, such as the techniques of sound production on the piano and the influence of dynamics and pedaling on it. Thus, researchers whose scientific works are devoted to the problems of piano sound quality, focused on piano sound production. In The Complete Theoretical and Practical Piano School, CarlCzerny distinguishes between the following types: legatissimo (for melodic fragments), legato (for melody), portamento (for some "heavy" sounds), staccato (for short, fragmentary sounds) and marcatissimo (for virtuoso staccato performance) (Черни, 1974: 98-127).

The works of Hugo Riemann became a new impetus in the research of the principles of expressive sound formation and organization by the performer of a musical form. In The Comparative School of Piano (Leipzig, 1883), the musicologist and teacher-performer introduces the terms non legato, legattisimo, mezzolegato, mezzostaccato (leggiero), carezzando (light touch and finger movement to the edge of the key).

EugeneTetzelinhisbook"ModernPianoTechnique" (Тетцель, 1929) considers the following types of sound production: legatissimo, legato, leggiero, staccato.

According to the memories of Teodor Leshetytskyi's students, during the classes the teacher paid considerable attention to the quality of sound, expressiveness of performance and the ability to sing a melody, distinguished legato, nonlegato and staccato. The virtuoso passages were not considered separately, but necessarily in the context of the work being performed. T. Leshetytskyi himself claimed that he borrowed such methods of work from K. Cherny almost without changes and additions, although researchers and music critics called it "Leshetytskyi's Method". The music teacher did not require his students to practice the instrument for many hours, focusing on the ability to mentally hear the future sound of a piece of music.

The methodical system of the Czech pianist and musician-teacher Vilem Kurz was based on the development of all professional skills of piano playing, including the piano culture of sound; perfect performance technique based on a combination of trained finger playing and the work of the entire playing apparatus of the pianist-performer; transparency and clarity in the interpretation of the texture and form of a musical work as a whole; extremely attentive attitude to the musical text. In the work "Technical foundations of piano playing" V. Kurz notes such techniques of piano sound production as staccato (with movement from above or from the key), legato, legatissimo, non legato. Particular attention in the work is paid to the peculiarities of the cantilena.
Ariadne Birmak distinguishes the following types (elements) of piano technique: "pearl", finger glissando, martellato, leggiero.

As it is seen, the techniques of the piano sound production are quite diverse. However, it should be noted that their use is directly related to the content and style of the piece of music.

Taking into account the peculiarities of the musical texture, the types of piano technique are divided into small (gamut and gamut-like passages; melismata; finger rehearsals; arpeggio; trill; groups covering no more than five notes without changing position, etc.) and large (octaves, chords and jumping, tremolo, etc.). Let's analyze the main types of piano finger technique.

Legato (Italian - connected) is a method of sound production that requires a long sound connecting performance. In piano technique, this method occupies a leading position. According to J. Ghat, the main condition for performing legato is the continuity of sound, which is expressed in the fact that the appearance of a new sound is manifested only in a change in the number of oscillations (strings), in other words - in the pitch. Since, due to the mechanical features of the piano, the pianist-performer cannot change the pitch of the sound without interrupting the sound, to obtain legato it is necessary that the new sound sounds as inconspicuous as possible (Гат, 1967: 161-162).

Staccato (Italian - intermittent, separate) involves the extraction of intermittent, short sounds. Staccato requires a performance in which the tones are not directly adjacent to each other, but clearly separated from each other at least by the slightest pauses.

The mortellato technique is used in cases when the content of the performed work requires clarity and density of sound. It is important that the pianist-performer uses oscillating movements (swing of the forearm and hand).

"Pearl technique" gives the sound lightness and sonority. According to A. Birmak, in order to achieve the desired sound in the "pearl technique", it is necessary to use tenacious grasping movements of sliding fingers under the palm.

Leggiero (Italian - easy, graceful) - another finger technique, which to achieve the desired sound result requires light strokes of rounded fingers. Moving on the keyboard happens with the use of flexible wrist movements while supporting the shoulder girdle and upper arm.

Melodic technique is used as a means of performing works in the nature of cantabile, melodic passages, etc. Performing a melodic technique requires the performer to be able to "transfuse" sound from note to note. 
Portamento (Italian - to transfer the voice) provides for the performance to be unrelated, separate, but not short sounds. In this case, a separate, emphasized articulation of each sound is important. In this case, the performance should be long, but not coherent.

Dynamics (Greek - force) has a direct influence on piano sound formation - the most important means of musical expression, which is embodied in the volume of sound. At the same time, we highlight the following factors on which the choice of a dynamic nuance depends: the drama and style of the performed musical work, the embodied artistic image, as well as external factors such as the acoustics of the instrument and the hall.

Like light and shadow in painting, dynamics help create psychological and emotional effects in music. The dynamic changes that occur during the sound embodiment of a musical thought are perceived as an emotional reflection and are based on associations and analogies that arise in the listener's mind. For example, including bright and strong emotions, the sphere of dynamic forte can express both tragic and joyful images. Fortissimo has the ability to evoke associations with powerful, majestic images, as well as to awaken feelings of fear, depression and more.

In the field of piano, pianissimo the images of sadness, grief, as well as mystery, peace and tenderness are engraved. Using inflections of crescendo and diminuendo (decrescendo), the artist can create the effects of "approaching" and "fading away".

In the aspect of piano sound formation, a special difficulty is the performer's mastery of the "extreme" capabilities of the instrument. Thus, the pianissimo requires extreme sensitivity in the process of sound production: the maximum clarity of articulation should be achieved with a minimum load on the keyboard. In contrast, the performance of fortissimo requires the involvement of all the power reserves of the pianist-performer - the weight and impact energy of the hand and body.

Thus, in order to perform musical and intonational activities, the pianist-performer must master all the gradations of piano sound, which are between the boundaries that $\mathrm{H}$. Neuhaus defined as "not yet a sound" and "no longer a sound" (Нейгауз, 1988: 68).

The pedal plays an extremely important role in the process of piano sound production. In this aspect, A. Rubinstein's statement is widely known: "the pedal is the soul of the piano". The value of the pedal is primarily to expand the amplitude of piano expression. In this case, the use of pedals on the piano should be determined by the need to change the sound, i.e. the method of its formation (mixing sounds, bass lengthening, etc.) or timbre, length, etc.
The origins of the pedal-sostenuto are in the organ keyboard-like pedal. In the modern version, the investigated pedal serves to delay the selected dampers in the raised state. Yes, the dampers raised by pressing the pedal are locked and remain in this state until the pedal is removed by the performer. At the same time, other dampers function as usual, including in relation to the right pedal. The use of the pedal is justified when performing music that is characterized by a complex texture, and requires the lengthening of individual sounds, as a rule in the lower register.

In the context of sound production, the right pedal has a direct effect on the sounds reproduced at the time of its pressing. In this case, the role of the pedal is not only to lengthen the sound, but also to improve it. This effect is achieved by means of raised dampers, which from the total number of raised strings, by resonance, lead to a compatible oscillation of the string, for which these sounds themselves are overtones. Due to this, the sound produced by the performer becomes more colorful and saturated.

S. Feinberg identifies the following leading functions of the right pedal: decorative, acoustic, tectonic, spatial, working, compromise, preliminary, direct, delayed, intentionally duplicated and melodic ones (Фейнберг, 2017: 335), which are closely interrelated in piano practice. Yes, if the pedal is used primarily to give the sound new qualities (softening or additional timbre), such a pedal is decorative or timbre, and is widely used in the music of romantic composers.

The left pedal originated more than half a century earlier than the right one, and was a double-shift mechanism. Thus, the structure of modern pianos provides three strings for each key in the middle and upper registers; two strings in the bass and one string for each key on the lowest notes. Pressing the left pedal shifts all the hammers to the right, which leads to their impact on the lowest notes only the left part and in the bass register - only one string, in the middle and upper registers - two strings instead of three. The timbre and dynamic effects resulting from the use of the left pedal are inextricably linked: achieving clearer dynamic shades, the performer at the same time gets a slightly different timbre color of the sound, and vice versa.

Thus, among the means of expression that the pianist has, the leading place belongs to the system of piano pedals: right (damper), left and middle (sostenuto). Collectively, the considered pedal mechanisms have an extremely important influence on the system of piano sound production - prolongation, dynamics and timbre of the sound.

Conclusions. Conscious piano intonement, being the sound embodiment of musical thought, finds its direct expression through the specifics of sound formation on the studied instrument. The latter is inex- 
tricably linked with sound production techniques, dynamics and pedaling.

The analysis does not cover all the issues related to the study of the features of piano sound formation as a parameter of performance intonement.
Prospects for further research are to consider in more detail the performance techniques used by pianists in the process of artistic intonation, to clarify the factors influencing the formation of the piano sound.

\section{BIBLIOGRAPHY}

1. Асафьев Б. Музыкальная форма как процесс. Москва : Книга по требованию, 2012. 376 с.

2. Бондар Є. Надекспресивне інтонування в контексті сучасної хорової творчості : автореф. дис. ... канд. мистецтвознавства : 17.00.03. Одеса, 2005. 20 с.

3. Веркіна Т. Актуальне інтонування як виконавська проблема : автореф. дис. ... канд. мистецтвознавства : 17.00.03. Одеса, 2008. 16 с.

4. Гат Й. Техника фортепианной игры. Будапешт : Атэнэум, 1976. 244 с.

5. Кирнарская Д. Психология специальных способностей. Музыкальные способности. Москва : Таланты-ХXI век, 2004. $496 \mathrm{c}$.

6. Колоней В. Пластичне у фортепіанно-виконавському інтонуванні : автореф. дис. ... канд. мистецтвознавства : 17.00.03. Київ, 2004. 18 с.

7. Малинковская А. Искусство фортепианного интонирования : учебник для вузов. М. : Издательство Юрайт, 2019. $323 \mathrm{c}$.

8. Нейгауз Г. Об искусстве фортепианной игры. Записки педагога. Москва : «Музыка», 1988. 143 с.

9. Тетцель Е. Современная фортепианная техника. Москва : Музторг, 1929. 88 с.

10. Фейнберг С. Пианизм как искусство. Учебное пособие. Санкт-Петербург : Лань; Планета музыки, 2017.560 с.

11. Черни К. Полная теоретическая и практическая фортепианная школа. Киев : Музична Украина, 1974. C. $98-127$.

\section{REFERENCES}

1. Asafiev B. Muzykal'naya forma kak protsess [Musical form as a process]. Leningrad: Music, 1971. 376 p. [in Russian].

2. Bondar E. M. Nadekspresyvne intonuvannya v konteksti suchasnoyi khorovoyi tvorchosti [Overexpressive intonation in the context of modern choral creativity] (Extended abstract of Candidate's thesis). The Odessa National A. V. Nezhdanova Academy of Music, 2005. 19 p. [in Ukrainian].

3. Verkina T. B. Aktual'ne intonuvannya yak vykonavs'ka problema [Topical intonation as a performance problem]. Petro Tchaikovsky National Music Academy of Ukraine. Kyiv, 2008. 19 p. [in Ukrainian].

4. Gat Y. Tekhnika fortepiannoy igry [The technique of the piano]. Budapest: Ateneum, 1976. 196 p. [in Russian].

5. Kirnarskaya D. K. Psikhologiya spetsial'nykh sposobnostey. Muzykal'nyye sposobnosti [Psychology of special abilities. Musical abilities]. Moscow: Talanty-XXI vek, 2004. 496 p. [in Russian].

6. Koloney V. O. Plastychne u fortepianno-vykonavs'komu intonuvanni [Plastic in piano-performance intonation] Petro Tchaikovsky National Music Academy of Ukraine. Kyiv, 2004. 18 p. [in Ukrainian].

7. Malinkovskaya A. Iskusstvo fortepiannogo intonirovaniya : uchebnik dlya vuzov [The art of piano intonation: a textbook for high schools]. Yurait Publishing House, 2019. 323 p. [in Russian].

8. Neuhaus G. Ob iskusstve fortepiannoy igry. Zapiski pedagoga [On the art of piano playing. Notes of the teacher]. Moscow: «Music», 1988. p. 143 [in Russian]. sian].

9. Tetzel E. Sovremennaya fortepiannaya tekhnika [Modern piano technique]. Moscow: Muztorg, 1929. 88 p. [in Rus-

10. Feinberg S. E. Pianizm kak iskusstvo. Uchebnoye posobiye [Pianism as an art. Tutorial]. St. Petersburg: Lan'; Planeta muzyki, 2017. 560 p. [in Russian].

11. Cherni K. Polnaya teoreticheskaya i prakticheskaya fortepiannaya shkola [Complete theoretical and practical piano school]. Kiev: Musical Ukraine, 1974. pp. 98-127 [in Russian]. 